\title{
Culture-Based Education Improves National Insight
}

\author{
Dwi Ratna Sari ${ }^{1}$, Mukhamad Murdiono ${ }^{2}$ \\ \{dwiratna.2019@student.uny.ac.id ${ }^{1}$, mukhamad_murdiono@uny.ac.id ${ }^{2}$ \} \\ Universitas Negeri Yogyakarta ${ }^{1}$, Universitas Negeri Yogyakarta ${ }^{2}$.
}

\begin{abstract}
This article aims to describe the concept of culture based education at SMP Negeri 3 Banguntapan based on the Yogyakarta goverment education regulation. Culturebased education is needed for the continuity of the educational process and cultural preservation. Culture-based education is integrated into all activities in schools. The integration of culture-based education is based on the DIY Regional Regulation Number 5 of 2011 concerning the Management and Implementation of Culture-Based Education and the DIY Governor's Regulation Number 66 of 2013 concerning the Culture-Based Education Curriculum. research at SMP Negeri 3 Banguntapan. This research is descriptive research with a qualitative approach. The research subjects were stakeholders, teachers, and students. Data collection techniques in this study used interviews, observation, and documentation. The method of checking the validity of the data is using triangulation. Analysis of research data using inductive techniques with data collection, data reduction, data presentation, and conclusions. The application of culture-based education in increasing national insight through teaching and learning activities in the classroom, habituation, and extracurricular activities.
\end{abstract}

Keywords: education; culture-based education; national insight.

\section{Introduction}

National education aims to develop capacities and shape the nation's character and culture while also educating the nation's life and developing students' potential from a national perspective. Supporting this statement, [1] education will create morality engraved in oneself and is a person's inner strength. But to realize this noble goal is not easy. Various ways are done to make it happen. In response to this, the government seeks to realize the goals of national education through various means, among others, by perfecting the National Education system. An essential aspect of the national education system is the guideline in educational activities and institutions to achieve academic goals. Several learning experiences are communicated that reflect and are absorbed from people's lives. Learning in schools is developed by the conditions of the education unit, regional potential, and students. Based on this, the Yogyakarta government sees excellent potential in perfecting national education. Therefore, based on the high cultural potential, the Yogyakarta Government issued the Yogyakarta Special Region The Management and Implementation of Culture-Based Education Regulation No. 5 of 2011 and the Governor of the Special Region of Yogyakarta Regulation No. 68 of 2012, Concerning the Use of Noble Cultural Values in Educational Management and Implementation.

The creation of these regulations is because education and culture are closely related and cannot be separated. In essence, education is a civilizing process to live a decent and valuable life for himself and the life of his community and have a national insight to maintain the integrity 
of the Indonesian nation. Education is a process to bring about the desired changes in human behavior - education is a deliberate endeavor to maximize a student's potential. As a result, education is a process of cultural transmission to students as the nation's next generation. Culture and education are two elements that support each other so that both play an essential role in advancing a country, by combining culture and education is a very vital factor in efforts to educate the nation's life. The use of culture in education in Yogyakarta is an attempt to generate national values. National values are generally found in the cultural values of the people in Yogyakarta. These values become the rope of unity for the community. This national insight is essential for the current generation to make Indonesia safe, fair, prosperous, and face the challenges of globalization. Planting cultural values with national wisdom is the right step.

To achieve this goal, culture-based schools need to meet the leading indicators, namely culture-based pedagogy, culture-based curriculum, participation, and culture-based student performance assessment methods [2]. Culture-relevant pedagogy provides learners with a way to succeed in learning to maintain their cultural integrity and competence [3]. Students pride in their cultural heritage becomes a catalyst for lesson planning. A culturally responsive curriculum increases academic engagement, positive grade points, and artistic image. Values, norms, knowledge, beliefs, practices, experiences, and language, which are the basis of culture, are used in the teaching and learning of students in culture-based education [4].

Culture is formed over a very long period and is a gradual process. A culture can maintain its existence and be handed down from one generation to the next, so it is necessary to have a cultural intermediary between ages. One way that can be done is to carry out the process of inculcating cultural values in the field of education both in informal, formal, and nonformal education [5]. Various educational reforms around the world have been carried out to conquer globalization's, worldwide competition's, technical progress's, and societal transformation's challenges [6]. Education must strive for equality and make concerted efforts to address the cultural needs of students in balancing the existing ethnic diversity [7]. As a result, culturebased education is a mechanism that allows everyone to learn about science and technology throughout their lives. Based education is the foundation for teaching and learning about culture's values, norms, knowledge, beliefs, practices, experiences, and languages to pupils. The emergence of a culture-based education paradigm emphasizes modernism's assumption, This necessitates democracy in all aspects of human life. As a result, education must be managed optimally by providing the community with the broadest possible place for local values as part of the educational aims and contents. Citizens and the government collaborate in the planning, implementation, maintenance, and development of educational activities in this framework.

Schools need autonomy so that schools can control substantial changes and challenges to the global economy [8]. Stated that the higher the level the provision of school autonomy, which allows schools and instructors to teach a varied range of kids, is seen to benefit students [9]. Culture always exists in schools, as explained by culture invites to know together with how to be, understand, and do [10]. Culture-based education is the foundation for teaching and learning kids about indigenous culture's values, norms, knowledge, beliefs, practices, experiences, and languages. Culture-based educational strategies influence socio-emotional development and educational outcomes. Culture-based education strengthens community and is inherently between disciplines and local resource-based projects [11].

In this competitive era, the world of education, teaching, and learning must keep up with the times but must still instill cultural values in students. Based on this, culture-based schools are encouraged to promote curriculum changes that are supported by pedagogical abilities in the classroom [12]. In this context, the principal becomes an important aspect that facilitates the decentralization process in developing a culture-based curriculum [13]. When the leader's vision 
is well articulated to reach a common objective, it is vital to influence others. In addition, the principal has a significant influence in fostering culture-based schools and the professional development of teachers.

Culture-based schools are built to create and instill actual values and the spirit of nationalism in all school members, including making character education programs or policies, forming cultural schools, communicating them to all schools, maintaining cultural values, and respecting each other's achievements. parties in the school [14]. Cultural education can promote equality in diverse schools by recognizing and addressing imbalances through culturally responsive teaching [15]. Through a long process of forming culture, it is hoped that it will be able to form orderly community obedience and create a physically and mentally prosperous society. The aim of reforming the culture-based school curriculum is to develop cultural, pedagogical teachers to improve teaching and learning approaches and kids with the attitudes, knowledge, and skills they'll need to meet future problems [16].

The above description illustrates that education and culture are critical and cannot be separated so that a culture-based curriculum is created to perfect the national education system. The implementation of the culture-based curriculum itself has not been implemented thoroughly in various regions. Yogyakarta is one of the regions that has implemented a culture-based curriculum. It is hoped that implementing this culture-based curriculum can be helpful to add national insight to students and be a good step for the preservation of Indonesian culture.

\section{Research Methods}

This type of research is descriptive research using a qualitative approach. Qualitative research is used to investigate and comprehend the meaning of a number of individuals or groups of people who are thought to be involved in social or humanitarian concerns. This approach was chosen because this research intends to understand the notion of culture-based education in promoting national insight by SMP Negeri 3 Banguntapan, which has been predicted as a culture-based school. In this study, the objects or circumstances, and phenomena described are culturally based educational concepts developed to improve nationality insights in the classroom's learning process and activities According to the explanation, presented in the background of the problem, the implementation of the research was conducted by collecting responses, opinions, and information from related parties and collecting documents related to cultural-based education at SMP Negeri 3 Banguntapan.

Purposive sampling is a strategy that is used to collect data with a specific goal in mind for finding and determining informants employing researchers selecting certain people who are considered to be able to provide the following necessary data based on data or information obtained from previous informants, researchers can determine other informants who are deemed to provide more complete data. The stages that the researchers used in the data collection technique in this study were as follows:

a) In-depth Interview Method

Interviews are conducted to obtain information directly from the subject being studied. The discussion aims to explore information about the concept of culture-based education used in SMP Negeri 3 Banguntapan as a culture-based school to improve nationality insights in students.

b) Observation Method 
Observations are carried out by looking carefully and in detail at matters related to culturebased education at SMPN 3 Banguntapan ranging from actions, behaviors, speech, work processes, situations, and conditions created during the activation process.

c) Documentation Methods

This documentation is done to complete the information obtained in interviews and observations in the research. Documentation is done by collecting data sourced from archives and documents that have a connection to the investigation. Researchers use documentation techniques in this study to obtain biological data in documents, photos, written rules, etc. This data further strengthens the data obtained from interview techniques and observations.

\section{Results and Discussion}

\section{1 cultural-based education planning}

Culture-based education in improving students' nationality insights implemented by SMPN 3 Banguntapan combines with the school's vision, mission, and objectives. This is done so that the school has a clear foundation related to the strategy that will be implemented. This stage of planning becomes the primary basis of culture-based education. Various kinds of program planning applied SMPN 3 Banguntapan by the theory that planning is a concept of how an activity will occur [17]. The regulation of the Province of Yogyakarta Special Region No. 5 of 2011 concerning the Management and Implementation of Culture-Based Education, as well as the regulation of the Governor of the Special Region of Yogyakarta No. 68 of 2012 concerning the Application of Noble Cultural Values in the Management and Implementation of E-Learning, govern the planning phase conducted by SMPN 3 Banguntapan. The details of the program to be implemented have been well prepared by a special team assigned as coordinators of cultural-based education programs.

Tabel 1. Cultural-Based Education Program Plan

\section{Program}

Integrated into all subjects

Local content and peculiarities

learning

Extracurricular activities

Habituation program (hidden

curriculum)

Visualization

\section{Information}

All subjects are required to integrate the noble values of culture and national insight

1. Local content that is Javanese

2. The individual lessons of karawitan, batik, and dance. Extracurricular activities integrated into national insight

1. Habituation of greetings in Javanese

2. Habituation of unggah-Canggu to older people and compassion

1. Bell change of lesson hours in the form of gamelan music

2. Ornaments and Javanese decorations such as batik motif paintings on school walls

Culture-based education at SMPN 3 Banguntapan is implemented through five planned programs, the first integrated into all subjects. The integration of national wawasam in learning responds to several weaknesses in eroding the love of the homeland due to globalization and the replacement of local culture with modern culture. The integration in question includes 
implementing learning activities that facilitate the practice of values in each activity inside and outside the classroom for all subjects. All subjects are also assumed to have a mission in building the national insight of learners [18]

Second, local content and distinctive learning are curricular activities that help students build competences that are adapted to the region's qualities and potentials, such as regional excellence or debuting with local wisdom.. The target of learning local knowledge is the advancement of cultural values cultivation. Honesty, accountability, discipline, environmental sensitivity, and cooperation are examples of cultural values. The planting of these values is included into the conditioned learning process so that these values might become attitudes and behaviors in everyday life. The local content applied by SMPN 3 Banguntapan is Javanese language learning. In addition, local content and peculiar learning can be done by giving teachers tasks in groups observing and identifying the culture or resources that exist in the residential environment.

Third, Extracurricular activities are one of the potential media for developing a student's character and improving their academic performance. The process of a habit developed by SMPN 3 Banguntapan in extracurricular activities is to require students to choose and participate in cultural-based extracurricular activities, including karawita ectracurikuler, batik, traditional dance, and Pencak Silat. Cultural-based extracurricular activities can reflect cultural values to students and play a role in improving national insight in preserving the nation's culture.

Fourth, the hidden curriculum program. In the framework of culture-based education can be integrated through daily habituation in schools. Habituation activities in students can be done with various kinds such as through multiple programs, and conducive school culture will internalize cultural values in students. Habituation activities are carried out through the hidden curriculum, an educational unit activity that is general and not directly related to a subject to help the development of learners according to their needs, potentials, talents, and interests. Thus these activities are expected to have a meaningful contribution to students' success in schools, especially for the success of cultural-based education.

Fifth, the visualization of a culture-based school is visualized by creating a school branding that shows the school has uniqueness, distinctiveness, and excellence. Branding is a way of distinguishing one school from another and the message recorded in one's memory about a school. School branding demonstrates the strength and excellence of schools based on the potential, environment, traditions, and support of the community and all school residents. The branding of a culture-based school conducted by SMPN 3 Banguntapan is reflected in the school's appearance, atmosphere, and achievements in academic and non-academic fields. School branding at SMPN 3 Banguntapan in visualizations such as walls painted batik motifs, displaying puppets, mottos, and moral messages using Javanese characters and languages, and school bells that use instruments and sing the Javanese language. The school's branding will be able to develop the uniqueness, excellence, and competitiveness of the school as a characteristic of the school. School branding is also able to improve the positive image of the school to increase the support of school residents and the community.

\subsection{Culture-Based Education at SMP Negeri 3 Banguntapan}

The application of culture-based education in SMP Negeri 3 Banguntapan produces students who have broader national insight in addition the cultivation of cultural values can be achieved through various means, namely through the refraction of cultural values, moral knowledge, feelings and love for cultural values, moral actions, and civility [19]. Analysis of the results of 
the implementation of culture-based education at SMP Negeri 3 Banguntapan based on school observations, interviews with stakeholders and students, and documentation about the school.

Culture-based education is defined as an education that is organized to meet national educational standards and is enriched with excellence based on noble cultural values so that students can actively develop their potential to become superior human beings, insightful nationalities, intelligent, visionary, and sensitive to the environment of cultural diversity, as well as responsive to the development of culture. Quality standards of culture-based education include content standards; process standards; competency standards of graduates; standards of educators and educational personnel; standard facilities and infrastructure; management standards; financing standards; and education assessment standards (P.P. No. 19/2005).

First, content standards: contains a basic framework and structure of a culture-based educational curriculum that integrates noble cultural values with science, education, technology, humanities, arts, sports, and social activities. Second, the standard of the process: promoting the active participation of learners by paying attention to personal uniqueness, the value of freedom of creativity, decency, order, happiness, togetherness, justice, and mutual respect. Third, SKL: Graduate competency standards include attitude, knowledge, and skills. The Governor's Regulation governs further provisions on attitudes, knowledge, and abilities. Fourth, the means Educators and educational professionals must adhere to the professional code of conduct and comprehend the noble value of culture; they must also develop an understanding of and application of civilization's noble ideals. Educators and academic personnel who do not carry out the obligation to build awareness and use noble values are subject to administrative sanctions. Fifth, surpass standards: covering the SNP as a minimum service standard coupled with infrastructure and facilities that facilitate the implementation of culturally centered education. The provision of samples is the responsibility of the Local Government to support the implementation of cultural-based education in international school start-ups, international schools, and special education. The local government helps providing infrastructure and facilities to aid in the implementation of culture-based education. The provincial government supervises the assistance of facilities and infrastructure.

Sixth, education management standards: education management standards are used for the basic framework of educational governance on a formal, nonformal, and informal cultural-based path. The management of legal pathway education units is carried out through primary and secondary education levels by implementing school-based leadership. The management of nonformal pathway education units is carried out by implementing community-based management. The management of nonformal pathway education units is carried out by implementing community-based management. Informal education management is managed independently by families or the community.

Seventh, the financing standard: the financing standard consists of investment costs, operational costs, and personal costs. The local government is responsible for financing to support the implementation of special service education by its authority. The provincial government helps finance implement culture-based education in education units in formal, nonformal, and informal channels organized by the community. The local government supervises financing assistance. Eighth, assessment standards: educational assessments include: mechanisms, procedures, and assessment instruments of learners' learning outcomes. Assessment is carried out with a continuous evaluation approach. Culture-based Learning in Improving the Quality of Education in Schools and authentic evaluation using various methods. Continuous evaluation is the evaluation of learning outcomes followed by follow-up. Data of learning evaluation results are used as materials to improve the learning program, improve learning weaknesses, and tutor students who need it. 
The integration of culture-based education is integrated into learning in the classroomteachers, in carrying out the learning process, insert material about nationality insights in students. In addition, teachers also apply a culture of habit to students. This integration aims to improve the nationality and culture of students, increase students' awareness to improve manners, and upload in daily life in the community. The existing theory that learning by applying a culture-based curriculum is an absolute thing at any level of education [20]. The idea is appropriate because education without being based on cultural values will not create students who are national and cultured. Therefore, culture-based education in SMP Negeri 3 Banguntapan as a culture-based school is the right step.

The purpose of implementing culture-based education at SMP Negeri 3 Banguntapan is to improve national insight and change the attitudes and behaviors of students to be more positive. The application of a culture-based curriculum can expand students' knowledge. Students will know the cultural excellence in the community, understand various aspects related to culture. Students will be able to process materials and participate in various activities linked to creative brilliance in order to maintain cultures, traditions, and resources that can compete nationally and internationally. Students are required to love their homeland, have faith in the future, and desire to develop the potential of existing cultures so that the region can grow in line with the needs of globalization and the evolution of the times as a result of the application of culture-based education.

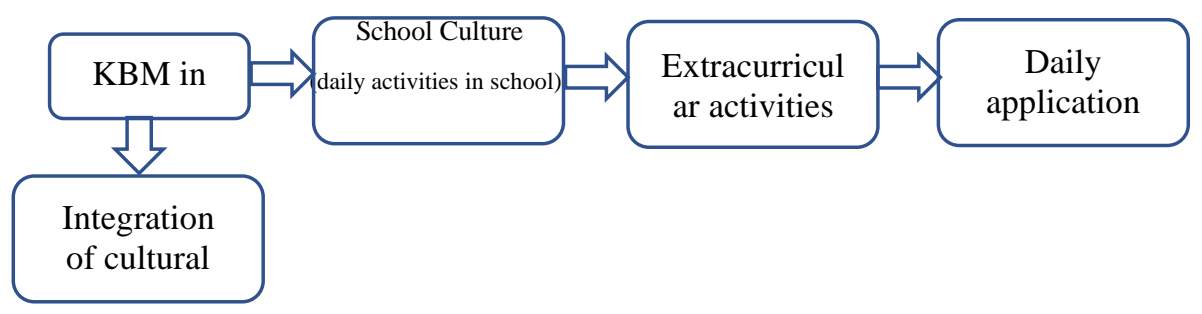

Fig.1. Development of Culture-Based Education in Improving National Insight

Cultural-based education applied in SMP Negeri 3 Banguntapan uses a curriculum that is oriented towards preparing graduates who are national and cultured. That is, each graduate can display behaviors according to the cultural values that develop in society. The culture-based curriculum at SMP Negeri 3 Banguntapan is also a form of curriculum innovation that prioritizes the development of student potential, civilized and dignified, and this culture-based curriculum is associated with the order of humanitarian values prevailing in the community. Local culture or wisdom is traditional customs and customs carried out by people until now still maintained by the community.

In addition, the existence of a culture-based curriculum that is integrated into learning and daily activities in schools is expected to prevent students from entering into the poor cultural environment of the community and have a role in the preservation and development of culture. The hope is that in local culture or wisdom, there is a science that can be used in the development of the country to support national action to be more efficient. Local insight shows the identity of the community's local culture, which is then developed for the community's welfare [21]. Comprehensively the culture-based curriculum combines academic, cognitive aspects with nonacademic aspects. Based on the explanation, the basis of integrating a culture-based curriculum in SMP Negeri 3 Banguntapan is the privilege and wealth of values contained in cultural assets 
that include the following. First, noble values are expressed in various artistic expressions placed in every corner of the school, such as hamemayu hayuning Bawana, golong gilig, sawiji, greget, sengguh, ora mingku; and noble values such as spiritual values, personal moral values, social values, and nationalism values are applied in school activities. Second, cultural products or artifacts in the form of cultural artworks and other works are loaded with noble values, including local physical architecture rich with the value of harmony, beauty, and robustness. Third, cultural activities are applied continuously, such as attending cultural festivals and commemorating Pahing Thursday.

The cultural values contained are used to give meaning to a concept and importance in communication between members of the community. Cultural-based learning that is so important in people's lives requires a culture to be a source of values from cultural education and the nation's character. The cultural-based education curriculum is expected to be able and commits to the following, namely, able to identify the right and affordable cultural elements to be an integrated part in education that is managed, design, and implement in earnest a culturebased education curriculum that is by the learners, monitor, assess, and control continuously and the effectiveness and quality of implementation, as well as the results, achieved d culturallybased education curriculum.

\section{Conclusion}

Culture-based education refers to the juridical basis of cultural education issued by the Yogyakarta Special Region Government, namely Yogyakarta Special Region Regulation No. 5 of 2011 concerning the Implementation of Culture-Based Education and Regulation of the Governor of the Special Region of Yogyakarta No. 68 of 2012 concerning the Application of Noble Cultural Values in the Management and Implementation of Education that serves to preserve the noble values of culture and national insight as mo valuable in realizing more meaningful learning and teaching. Efforts to realize a culture-based curriculum as a capital in learning are carried out through various provisions and strategies that ensure the effectiveness of integration of culture-based curriculum must meet several prerequisites, namely the existence of a conducive school climate and the teacher's view that all students can inherit the noble values of culture. While the strategy used in culture-based education at SMP Negeri 3 Banguntapan is implemented through five planned programs, firstly integrated in all subjects, the second is applied in local learning. third, extracurricular activities, the four hidden curriculum programs within the framework of culture-based education can be integrated through daily habituation in schools. fifth, the visualization of a culture-based school is visualized by creating a school branding that shows the school has the uniqueness and excellence of the school.

Acknowledgments. The author would like to thank Dr. Mukhamad Murdiono, M.Pd as a supervisor who patiently and kindly gave direction and guidance for the author in completing this paper. The authors also thanked Yogyakarta State University Postgraduate Program for providing support for the publication of this paper.

\section{References}


[1] Albatani, A.M., \& Madkur, A. Think globally, act locally: the strategy of incorporating local wisdom in foreign language teaching in Indonesia. International Journal Of Applied Linguistics And English Literature. 2018; 7(2), 1-8.

[2] Asmani, J.M. 2012. Pendidikan Berbasis Keunggulan Lokal. Yogyakarta: DIVA Press

[3] Basyari, H.I.W. Nilai-nilai kearifan lokal (local wisdom) tradisi memitu pada masyarakat Cirebon (studi masyarakat Desa Setupatok Kecamatan Mundu). Jurnal Edunomic. 2014; 2(1): 45-55.

[4] Caldwell, B. J \& J. M. Spinks. The Self-Transforming School. London: Routledge, 2013

[5] Candra, W., Manshuruddin., Zulham., et al. Character building through school culture development in the Senior High School of Panca Budi Medan. Saudi Journal Of Humanities And Social Sciences. 2020; 5(1): 9-16. DOI: 10.36348/sjhss.2020.v05i01.002

[6] Chusorn., Pornpimona, A., Chusorn,W., \& Prayuthc. 2013. Strategy challenges the local wisdom applications sustainability in schools. Journal Procedia Social And Behavioral Sciences. 2013; 112, 626 - 634. DOI: 10.1016/j.sbspro.2014.01.1210

[7] Dee, T. S. \& Penner, E. K. The causal effects of cultural relevance. American Educational Research Journal. 2017; 54(1): 127-166. DOI:10.3386/w21865.

[8] Hartnell, C. A., Ou, A.Y. \& A. Kinicki. Organizational culture and organizational effectiveness: a meta-analytic investigation of the competing values framework's theoretical suppositions. Journal of Applied Psychology. 2011; 96(4): 677-694. DOI.org/10.1037/a0021987.

[9] Hasan, A., Othman, Z \& Majzub, R.M. Using active, creative, effective, and joyful (ACEJ) learning strategies toward English achievement and behavioral changes among primary school students.

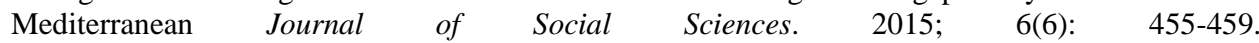
doi.org/10.5901/mjss.2015.v6n6p455

[10] Kana'iaupuni, S., Ledward, B., \& Jensen, U. Culture-Based Education And Its Relationship To Student Outcomes. Honolulu: Kamehameha School, Research \& Evaluation, 2010

[11] Lee, T., Yin, C.C \& James, K. Curriculum reform with a school-based approach: intellectual, structural and cultural challenges. Journal Taylor \& Ferancis Group. 2017; 38(3): 278-301. DOI.org/10.1080/13632434.2017.1386647.

[12] Lestari, W., Fatinatus Selvia, \& Rohmatul Layliyyah. Pendekatan Open-ended Terhadap Kemampuan Metakognitif Siswa. At- Ta'lim : Jurnal Pendidikan. 2019; 5 (2): 184-197. https://doi.org/10.36835/attalim.v5i2.263

[13] Lyons, R., Dsouza, N., \& Quigley, C. Viewing equitable practices through the lens of intersecting identities. Journal Cultural Studies Of Science Education. 2016; 11(4): 941- 951. DOI:10.1007/s11422-015-9699-z

[14] Mulyasa, H.E. (2011). Manajemen Pendidikan Karakter. Jakarta: Bumi Aksara

[15] Mungmachon, M. R. Knowledge and local wisdom: Community treasure. International Journal of Humanities and Social Science. 2012; 2(13) : 174-181. doi:10.30845/ijhss

[16] Paris, D. The right to culturally sustaining language education for the new American mainstream: An introduction. International Multilingual Research Journal. 2015; 9(4): 221-226. DOI.org/10.1080/19313152.2015.1092849

[17] Reyhner, J., Willard, S.G., Louise, L., et al. Respect We Legacy According To Culture Approaches To Teaching Indigenous Students. New Mexico: Northern Arizona University, 2011

[18] Suyitno, I. Pengembangan pendidikan karakter dan budaya bangsa berwawasan kearifan lokal. Jurnal Pendidikan Karakter. 2012; 2 (1): 1-13. DOI.org/10.21831/jpk.v0i1.1307.

[19] Wang, Y. Education Policy Reform Trends In G20 Members. Dordrecht: Springer, 2013

[20] Zajda, J. Second International Handbook On Globalization, Education And Policy Research. 2nd Ed. Dordrecht: Springer, 2015

[21] Zohar, A \& Cohen, A. Large scale implementation of higher-order thinking (HOT) in civic education: the interplay of policy, politics, pedagogical leadership and detailed pedagogical planning. Journal Sciencedirect. 2016; 21: 85-96. DOI.org/10.1016/j.tsc.2016.05.003 